\title{
PELATIHAN PEMBUATAN MEDIA PEMBELAJARAN BERBASIS MULTIMEDIA MENGGUNAKAN POWER POINT DAN ISPRING BAGI GURU-GURU SMP 42 OKU
}

\author{
TRAINING MAKING BASED LEARNING MULTIMEDIA USE POWER \\ POINT AND ISPRING FOR TEACHERS JUNIOR HIGH SCHOOL 42 OKU
}

\author{
Joko Kuswanto $^{1 *)}$, Destiarini ${ }^{2)}$, Abdul Rahman ${ }^{3)}$, \\ Jumdapi Okta ${ }^{4)}$, Anggraeni Agustin Muris ${ }^{5)}$ \\ 1,2,3,4,5 Program Studi Informatika, Fakultas Teknik dan Komputer, Universitas Baturaja \\ email: jokokuswanto@unbara.ac.id
}

\begin{abstract}
Abstrak: Salah satu faktor yang mempengaruhi kualitas pendidikan adalah penyajian materi pembelajaran yang kreatif dan inovatif. Terkait dengan hal tersebut, maka perlu adanya media pembelajaran yang dapat menarik minat belajar siswa, sehingga suasana pembelajaran lebih nyaman dan menyenangkan. Disamping media dibutuhkan juga guru kreatif yang memiliki keahlian di bidang teknologi informasi dan komputer, maka penting dilakukan pelatihan pembuatan media pembelajaran berbasis multimedia menggunakan Power Point dan iSpring bagi guru-guru SMP N 42 OKU. Kegiatan ini dilakukan dengan harapan guru-guru dapat menggunakan atau memanfaatkan MS Power Point dan iSpring untuk pembuatan media pembelajaran yang dapat digunakan dalam proses kegiatan pembelajaran baik untuk guru maupun siswa. Hasil dari kegiatan yang telah dilakukan adalah guru-guru sudah mengerti dan memahami tentang multimedia dan peranan multimedia dalam pembelajaran. Selain itu guru-guru juga sudah memahami keuntungan menggunakan mampu membuat setiap langkah pengerjaan media pembelajaran berbasis multimedia menggunakan Power Point dan iSpring Suit.
\end{abstract}

Kata Kunci: Media Pembelajaran, Multimedia, iSpring

\begin{abstract}
One of factors affect the quality of education is learning presentation of creative and innovative matter. Related to this, the media should be education student learning, will attract so the learning more comfortable and agreeable. Besides media is required teachers creative with expertise in information technology and computer, so important training on preparing media based learning multimedia use Power Point and iSpring for teachers junior high school 42 OKU. This activity undertaken in the hope teachers can use or harness MS Power Point and iSpring media for making it can used in the process learning activities for both teachers and students. The result of the work being done is teachers had already discerned and understand about multimedia and the role of multimedia in their experiences. In addition teachers also are already proficient in advantage use able to make every step the implementation of the project learning media multimedia use Power Point and iSpring Suit.
\end{abstract}

Keyword: Learning Media, Multimedia, iSpring

\section{PENDAHULUAN}

Seiring perkembangan teknologi informasi dan komputer, salah satu faktor yang mempengaruhi kualitas pendidikan adalah penyajian materi pembelajaran yang kreatif 


\section{INTEGRITAS : Jurnal Pengabdian}

Vol 4, No 1, Juli 2020

ISSN 2580 - 7978 (cetak) ISSN 2615 - 0794 (online)

dan inovatif. Terkait dengan hal tersebut, maka perlu adanya media pembelajaran yang dapat menarik minat belajar siswa, sehingga suasana pembelajaran lebih nyaman dan menyenangkan. Berbagai macam aplikasi dapat digunakan untuk membuat media pembelajaran salah satunya adalah aplikasi iSpring.

Ispring sendiri adalah program yang berjalan "menumpang" pada piranti lunak yang sudah ada, dalam hal ini MS PowerPoint, yang umum dikenal dengan Add program, iSpring tidak dapat berjalan sebelum program MS PowerPoint terpasang pada perangkat komputer. Selain harus terpasang MS PowerPoint, komputer juga harus sudah terpasang flash player. Hal ini diharuskan karena iSpring menyediakan fasilitas untuk mengubah dokumen MS PowerPoint menjadi file flash, menyisipkan file flash ke dalam MS PowerPoint.

Aplikasi iSpring menyediakan fitur-fitur yang dapat mengembangkan materi bahan ajar dalam format power point menjadi materi multimedia dengan format html5 ataupun exe yang dapat dilengkapi suara (musik atau suara penyaji), video (tutorial contoh-contoh penjelasan materi) dan quiz maker (soal-soal latihan).

Dalam peningkatan kualitas pendidikan, dibutuhkan sumber daya manusia yang memiliki kompetensi di bidang IT yang cukup. Para guru sebaiknya memiliki keahlian dasar di bidang teknologi komputer, mengingat perkembangan informasi yang semakin pesat, tentunya wajib diimbangi dengan pengetahuan dan keterampilan sumber daya manusia yang kompeten di bidang tersebut.

Berdasarkan pemaparan di atas terkait dengan kebutuhan para guru SMP N 42 OKU, maka penting dilakukan pelatihan pembuatan media pembelajaran berbasis multimedia menggunakan power point dan ispring bagi guru-guru SMP N 42 OKU.

\section{METODE}

Berdasarkan permasalahan yang telah dipaparkan, maka kerangka pemecahan masalah atau solusi yang ditawarkan adalah memberikan penyampaian materi dan pelatihan kepada guru-guru yang ada di SMP N 42 OKU tentang tata cara pembuatan media pembelajaran menggunakan MS Power Point dan iSpring.

Kegiatan pengabdian ini dilakukan dengan harapan guru-guru dapat menggunakan atau memanfaatkan MS Power Point dan iSpring untuk pembuatan media pembelajaran yang dapat digunakan dalam proses kegiatan pembelajaran di SMP N 42 


\section{INTEGRITAS : Jurnal Pengabdian}

Vol 4, No 1, Juli 2020

ISSN $2580-7978$ (cetak) ISSN 2615 - 0794 (online)

OKU baik untuk guru maupun siswa. Selain itu dengan penggunaan media pembelajaran berbasis multimedia akan membuat proses pembelajaran lebih menarik, misalnya dari segi tampilan yang dikombinasikan dengan beberapa gambar ataupun animasi sehingga dapat meningkatkan motivasi belajar siswa.

Kegiatan pengabdian ini dilaksanakan di SMP N 42 OKU pada Hari Sabtu Tanggal 15 Bulan Februari 2020. Peserta yang terlibat sebanyak 15 orang yang merupakan guru dilingkungan SMP N 42 OKU.

Adapun pelaksanaan kegiatan pengabdian kepada masyarakat di SMP N 42 OKU ini meliputi:

1. Persiapan, meliputi: koordinasi teknis di lapangan; merumuskan permasalah yang dihadapi oleh pihak sekolah dan menyiapkan materi dan peralatan yang akan digunakan

2. Penyampaian materi tentang media pembelajaran dan pembuatan media pembelajaran dengan ispring

3. Evaluasi hasil pengabdian untuk mengetahui kendala selama pelatihan.

\section{HASIL DAN PEMBAHASAN}

Pelatihan pembuatan media pembelajaran dengan menggunakan Power Point dan iSpring bagi guru di SMP N 42 OKU direalisasikan pada Hari Sabtu, 15 Februari 2020. Untuk kelancaran pelatihan, peserta yang dalam hal ini guru-guru diminta membawa laptop atau notebook masing-masing.

Kondisi peserta yang hampir sama yaitu sudah memahami pembuatan media menggunakan power point memberi keuntungan, yakni dalam pelatihan tidak terkendala oleh keterampilan dasar menggunakan komputer sehingga pelatihan dapat difokuskan pada pembentukan keterampilan baru terkait penggunaan iSpring. Walaupun selama kegiatan bisa dikatakan berlangsung agak lambat karena harus mengikuti kecepatan peserta dalam memahami materi yang diberikan, namun secara keseluruhan di akhir pelatihan peserta ada yang sudah mampu membuat kreasi animasi sendiri yang menarik. Dengan demikian, para guru sudah mampu memproduksi media, ada yang masih sederhana, namun ada juga yang sudah baik.

Hasil dari kegiatan pengabdian masyarakat yang telah dilakukan di SMP N 42 OKU oleh Tim dosen pengabdian masyarakat sudah sesuai dengan yang diharapakan 


\section{INTEGRITAS : Jurnal Pengabdian}

Vol 4, No 1, Juli 2020

ISSN 2580 - 7978 (cetak) ISSN 2615 - 0794 (online)

dalam latarbelakan pengabdian. Guru-guru sudah mengerti dan memahami tentang multimedia dan peranan multimedia dalam pembelajaran. Selain itu guru-guru juga sudah memahami keuntungan menggunakan aplikasi multimedia, pengaruh penggunaannya dalam pembelajaran. Guru-guru sudah mampu membuat setiap langkah pengerjaan media pembelajaran berbasis multimedia menggunakan Power Point dan iSpring Suit.

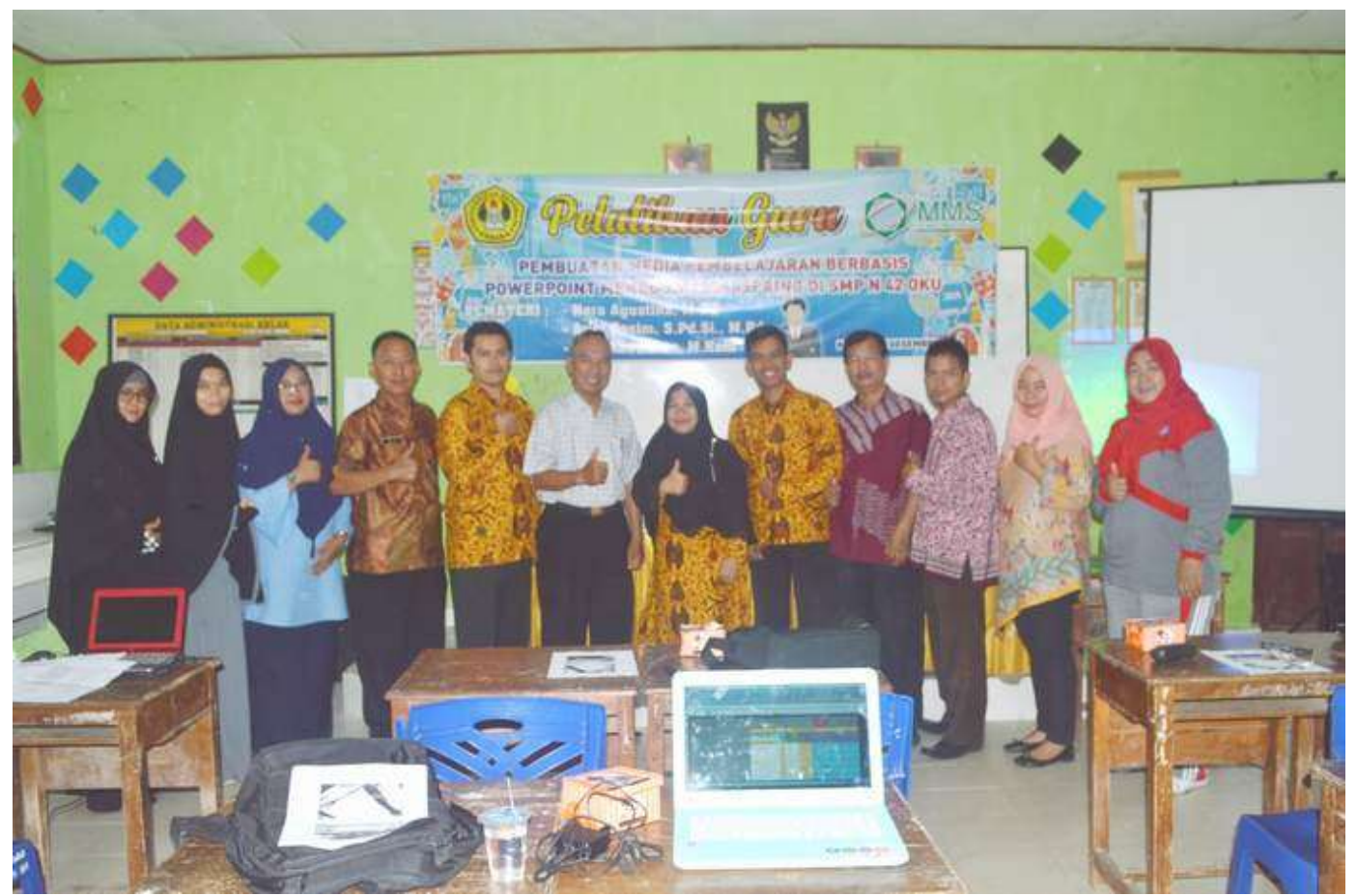

Gambar 1. Bersama beberapa peserta pelatihan 


\section{INTEGRITAS : Jurnal Pengabdian}

Vol 4, No 1, Juli 2020

ISSN 2580-7978 (cetak) ISSN 2615-0794 (online)

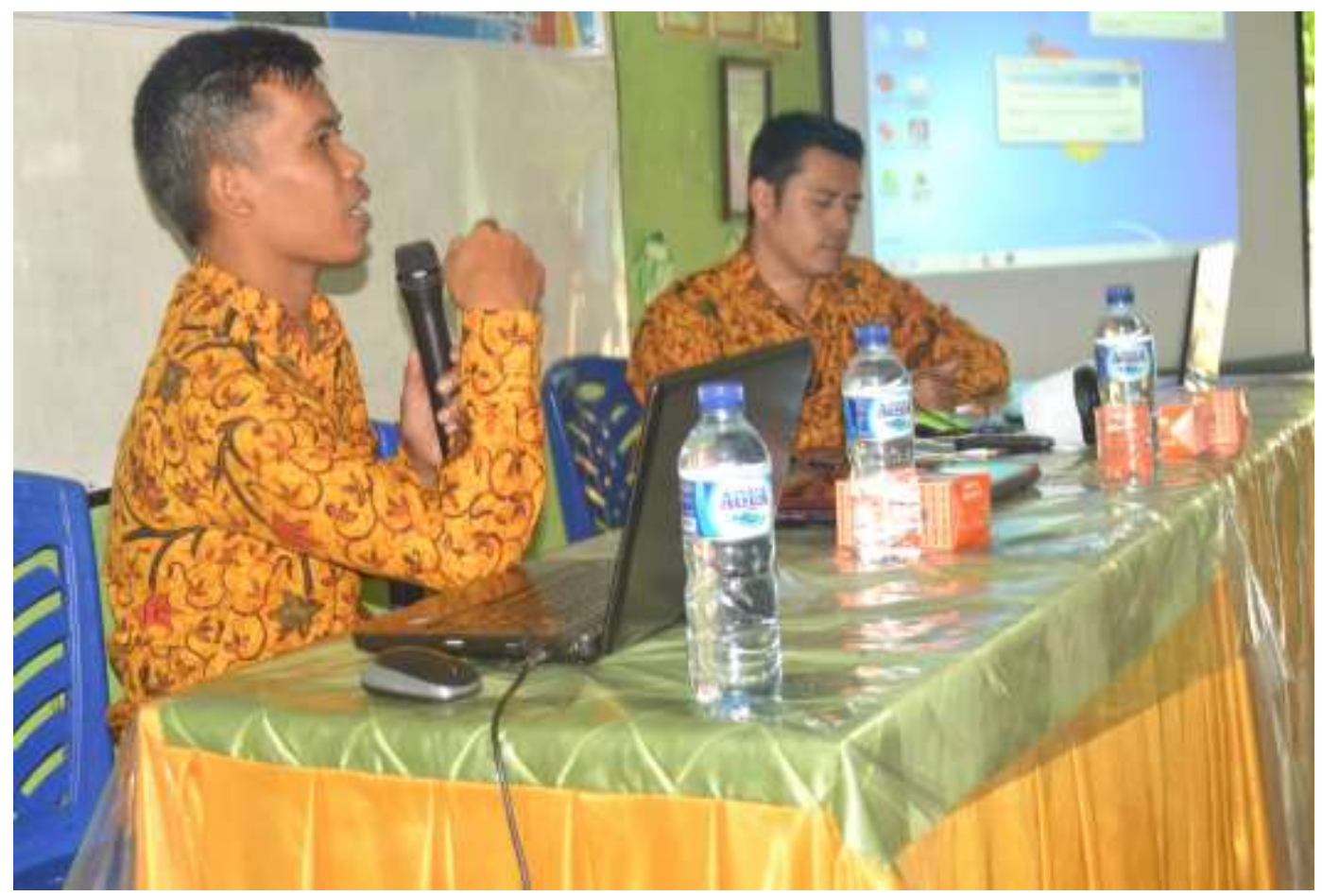

Gambar 2. Penyampaian Materi

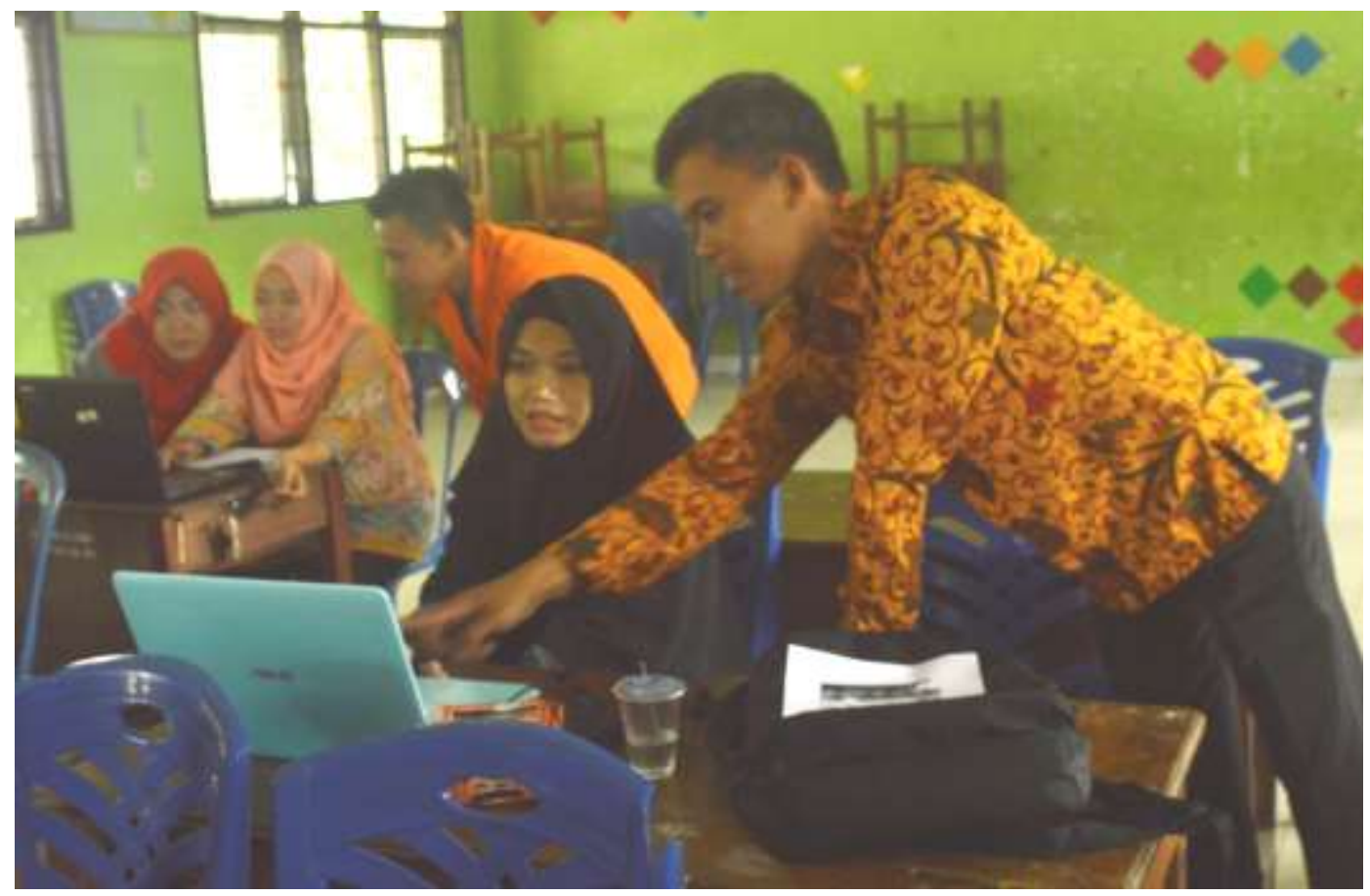

Gambar 2. Pendampingan saat praktek pembuatan media 
INTEGRITAS : Jurnal Pengabdian

Vol 4, No 1, Juli 2020

ISSN $2580-7978$ (cetak) ISSN 2615 - 0794 (online)

\section{KESIMPULAN}

Adapun kegiatan pengabdian masyarakat ini dapat disimpulkan bahwa pengabdian masyarakat yang dilakukan di SMP N 42 OKU dengan tema "Pelatihan Pembuatan Media Pembelajaran Berbasis Multimedia Menggunakan Power Point dan iSpring" memberikan manfaat luar biasa untuk para guru. Guru sangat antusias dan tertarik dengan penggunaan iSpring yang merupakan sebuah aplikasi bisa mereka gunakan untuk membuat media pembelajaran, guru dapat lebih mudah untuk membuat kuis atau evaluasi, lebih hemat waktu untuk pengoreksian soal yang telah dikerjakan oleh siswa serta mengurangi penggunaan kertas.

Akan tetapi, fasilitas seperti ketersediaan komputer / laptop saat proses pembelajaran berlangsung juga harus didukung oleh setiap sekolah. Karena dengan fasilitas yang baik dapat memudahkan dalam penerapan media pembelajaran yang telah dibuat dan dikembangkan oleh guru. Sehingga, sinergi yang baik dibutuhkan tidak hanya kreatifitas guru akan tetapi fasilitas juga harus sejalan demi tercapainya kualitas pembelajaran yang lebih baik lagi.

\section{UCAPAN TERIMA KASIH}

Ucapan terima kasih disampaikan kepada SMP N 42 OKU yang telah memfasilitasi kegiatan ini. Selain itu untuk peserta yang merupakan para majelis guru dilingkungan SMP N 42 OKU yang begitu antusias dalam mengikuti kegiatan ini.

\section{DAFTAR PUSTAKA}

Setiorini, I. L. (2018). Penyuluhan dan Pelatihan Membuat Media Pembelajaran Animasi Flash Kepada Guru Sekolah Dasar di Kecamatan Panarukan Kabupaten Situbondo, Jurnal Integritas Situbondo, 2(2), 91-100.

Soni, dkk (2018). Optimalisasi Pemanfaatan Google Classroom Sebagai Media Pembelajaran di SMK Negeri 1 Bangkinang, Jurnal Pengabdian Untuk Mu NegeRI, 2(1), 17-20.

Syah, A. Z., dkk (2018). Pelatihan Media Pembelajaran Interaktif Berbasis Multimedia Bagi Guru-Guru SMAN 02 Tanjungbalai, Jurdimas, 1(1), 1-6. 


\section{INTEGRITAS : Jurnal Pengabdian}

Vol 4, No 1, Juli 2020

ISSN 2580-7978 (cetak) ISSN 2615-0794 (online)

El Fauziah, U. N., Suryani, L., Syahrizal, T. (2019). Penerapan Google Classroom dalam Pembelajaran Bahasa Inggris Kepada Guru-Guru Bahasa Inggris SMP di Subang, Jurnal Abdimas IKIP Siliwangi, 2(2), 183-191. 